\title{
Universiteit
}

Leiden

The Netherlands

\section{From parts to wholes and back again}

Verhagen, Arie

\section{Citation}

Verhagen, A. (2002). From parts to wholes and back again. Cognitive Linguistics, 13, 403-439. Retrieved from https://hdl.handle.net/1887/2382

$\begin{array}{ll}\text { Version: } & \text { Not Applicable (or Unknown) } \\ \text { License: } & \text { Leiden University Non-exclusive } \\ \text { Downloaded from: } & \underline{\text { hicense }} \\ \text { https://hdl.handle.net/1887/2382 }\end{array}$

Note: To cite this publication please use the final published version (if applicable). 


\title{
From parts to wholes and back again
}

\author{
ARIE VERHAGEN*
}

\section{Abstract}

In this paper, I apply the usage-based conception of linguistic (primarily: semantic) structure (Langacker 1988, 2000) to a number of structurally different phenomena and their development over time. I argue that the same mechanisms are operative in the historical development of some complex conceptual structures that are not formally complex, and of some others where conceptual structure does correspond to formal structure. It is claimed that the usage-based conception-individuals acquire structured knowledge on the basis of an initially holistic, non-analytic understanding of expressions - plays a crucial role in explaining historical processes where the direction is reversed (contextual interpretations derived through inference becoming unitary conventional meanings). Futhermore, in the case of constructions, their 'local' properties, related most directly to their functions in usage, appear to be much more important for understanding their linguistic behavior than their general structural properties (such as being transitive or ditransitive, morphological or syntactic, etc.). The overall picture emerging from the discussion is that the coherence of a language (and, a fortiori, of language in general) should not be sought in properties of the linguistic system itself, but rather in processes, in individuals and in populations, that shape it.

Keywords: usage-based approach; construction grammar; language change; structure of grammar; Dutch way construction.

\section{Introduction}

In this article I want to explore a usage-based approach to the way knowledge of relations between parts and wholes in grammar develops and is organized, and show that such an approach can serve to unify different 
perspectives in the investigation of grammar in a radical manner. ${ }^{1} \mathrm{My}$ first example concerns a striking difference between the Afrikaans discourse marker inteendeel and the Dutch integendeel, 'on the contrary', from which it is derived historically. The second major illustration involves a comparative and especially historical analysis of way constructions in Dutch and English.

\section{Losing space}

The first example started as a personal linguistic experience. In 1999, a young South-African cognitive linguist came to Leiden to finish his Ph.D. Afrikaans is still sufficiently close to Dutch that a native speaker of Dutch can read it -with a little bit of effort, but still without special training. But once in a while, of course, misunderstandings are bound to arise. One case that struck me at the time as very special concerns the Afrikaans discourse marker inteendeel, derived from Dutch integendeel, which means 'on the contrary'. The majority of cases of inteendeel seem to be interpretable in a straightforward manner, for example:

(1) Dit impliseer egter nie dat die uiteindelike resultate van Botha (1988) verwerp word nie; inteendeel, sy gevolgtrekkings met betrekking tot die konseptualisering van reduplikasies sal juis handig blyk te syn.

'However, this does not imply that the final results from Botha (1988) are rejected; on the contrary, his conclusions concerning the conceptualization of reduplications will turn out to be useful.'

However, a few cases made me think something was wrong; the following is a clear example:

(2) Botha (1988) sluit tot 'n bepaalde mate by Moravcsik (1978) aan as hy aandui dat 'vermeerdering' die belangrikste betekeniseienskap is van reduplikasies. Inteendeel, in die formulering van sy interpretasiereël vir reduplikasies, word 'vermeerdering' aangedui as enigste betekeniswaarde ...

'Botha (1988) agrees to some extent with Moravcsik (1978) when he indicates that "increase" is the most important semantic property of reduplications. (literally: On the contrary) In fact, his rule of interpretation for reduplications marks "increase" as the only semantic value ...'

As it turned out (and as indicated in the translation), what was meant was actually better rendered by "in fact" than by the literal translation "on the contrary"; what the expression marked was reinforcement. It also turned 
out that this was not an isolated phenomenon. It is easy to find cases like (3) on the internet:

(3) Heelwat oulike idees gaan gewis gesteel word, inteendeel dit is reeds besig om te gebeur. ${ }^{2}$

'Quite a few brilliant ideas are certainly going to be stolen, (literally: on the contrary) in fact this is already happening.'

Another nice piece of evidence is the fact that the most recent edition of the standard Concise Dictionary of Afrikaans (Verklarende Handwoordeboek van die Afrikaanse Taal, HAT, electronic version, 1994) contains an explicit remark about this type of usage:

(4) ... OPM.: Inteendeel word soms foutiewelik gebruik waar geen werklike teenstelling bedoel word nie ..., bv. die vrugte is lekker soet; inteendeel, dit is sommer baie soet; ...

'... REMARK: Inteendeel is sometimes used wrongly where no real contrast is meant ..., e.g., the fruits are nice and sweet; on the contrary, they are just very sweet; ...'

When a dictionary starts making remarks like this, we can be sure that there is a language change going on. So there is really a conventional type of usage here that is not possible for the Dutch integendeel and English on the contrary. How can this be characterized, in a way that allows for an explanation of the change?

There is an important difference between sentential negation, in English with not, and morphological negation with the prefix un-, in that only the former evokes the coordination of two distinct perspectives, two mental spaces (cf. Fauconnier 1994; Verhagen 2000b, 2001), with opposite epistemic stances with respect to the same proposition. This can precisely be made observable in the behavior of the phrase on the contrary. In (5), the negation not evokes a second mental space besides the base space of the speaker, and it is this second mental space to which on the contrary can relate:

(5) Mary is not happy. On the contrary, she is feeling really depressed.

(6) \#Mary is unhappy. On the contrary, she is feeling really depressed.

But the prefix un- in (6) does not evoke a mental space distinct from that of the speaker, and thus there is nothing for on the contrary to relate to. The phrase in fact in present day English does not require the presence of such an alternative mental space; it is "just" a reinforcer of the speaker's own opinion, and thus it fits in both contexts:

(7) Mary is unhappy. In fact, she is feeling really depressed.

(8) Mary is not happy. In fact, she is feeling really depressed. 


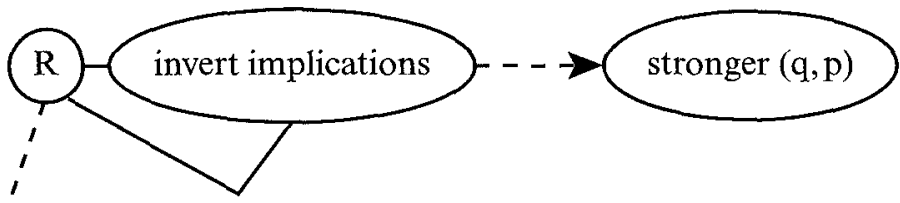

( $[p$ not $r]$ ) integendeel 'on the contrary' $(q)$

Figure 1. Linguistic analysis of " $p$, on the contrary $q$ ": from meaning to inference

But it is true that expressing an opinion contrary to an opinion you do not hold, normally also counts as a reinforcement of your own opinion; so in terms of the relationship between the speaker's own opinions, on the contrary in (5) and in fact in (7) and (8) are doing similar work. ${ }^{3}$ The way that this observation is usually accounted for, is in terms of an implicature (cf. Levinson 2000): an inference derived from the use of the expression in a context that allows the inference. In this case, the conventional meaning of the negative expression not $r$ evokes a mental space (distinct from the speaker's) with a positive epistemic stance towards $\mathrm{R}$. The expression integendeel $q$ 'on the contrary $q$ ' inverts the implications of $\mathrm{R}$ and marks $\mathrm{Q}$ as in some way its counterpart; as the speaker is known to have a negative stance towards $\mathrm{R}$, the expression of $\mathrm{Q}$ counts as a stronger statement than the previous one, i.e., a reinforcement of the speaker's first assertion (see Figure 1).

What must have happened in Afrikaans is that for many speakers, this former inference is now a conventional meaning of the word inteendeel, so that it is no longer necessarily a marker of opposition to a negated view, but a positive reinforcer of the speaker's own opinion. In other words: in present day Afrikaans the conventional meaning of $p$ inteendeel $q$ is " $\mathrm{Q}$ is a stronger statement than $\mathrm{P}$ ", and the original constraint that $p$ must contain a negation, has been lost.

Some evidence for this process can be found in the overall increase of the use of the word, for example in two translations of the Bible 30 years apart. It still occurs in negative contexts in the latest 1983 translation, but in ways that actually suggest a positive connection to the speaker's opinion, rather than a negative one to the negated view. A clear example is given in (9):

(9) (a) ... aangesien uit die werke van die wet geen vlees voor Hom geregverdig sal word nie, want deur die wet is die kennis van sonde.

(Romeine 3:20; 1953)

'... since from the deeds of the law no flesh will be justified for Him, for through the law is the knowledge of sin.' 


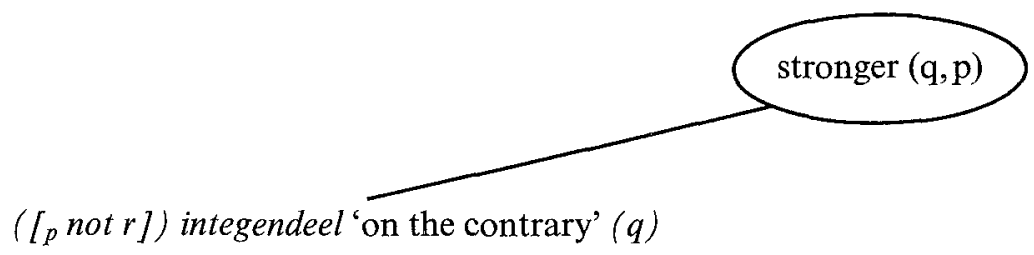

Figure 2. From usage to meaning 1

(b) Therefore by the deeds of the law there shall no flesh be justified in his sight: for by the law is the knowledge of $\sin$. (Romans 3:20; King James Version)

(c) Daarom sal geen mens op grond van wetsonderhouding deur God vrygespreek word nie; inteendeel, deur die wet leer 'n mens wat sonde is. (1983)

Therefore no man shall be absolved by God on the basis of keeping the law; on the contrary, through the law a man learns what $\sin$ is.

Where the 1953 Afrikaans translation has a positive causal connective (want 'for') between the clauses, just like the King James Version in English, the newer Afrikaans translation has inteendeel. I take this not as evidence for a negative interpretation of the relation by the 1983 translators, but rather as evidence for the growing potential of inteendeel to mark a relation in a positive manner itself.

This exposition is undoubtedly limited, but it suffices for one general point, namely that a linguistic analysis of the type depicted in Figure 1, going from meaning to inference, cannot be an adequate picture of the way that speakers represent these aspects of the interpretation of the expression. If the idea "stronger (q, p)" is always derived inferentially, then the meaning elements on which it is based cannot disappear without the inference itself disappearing, while we have just seen that the inference has become the meaning. Thus, for at least a substantial number of speakers, this idea must have had a direct connection to the expression in order to allow it to survive when the original meaning components were lost. In fact, this is what we actually should expect in a usage-based approach to the ontogenetic development of linguistic knowledge (Tomasello 2000). That is, a person's initial understanding of what a linguistic expression might mean comes from its being used in a context that is sufficiently transparent to associate the form with something the person understands that the speaker wants to communicate (see Figure 2).

It is only over time, with accumulating experience and especially sufficient evidence that integendeel 'on the contrary' (unlike other 


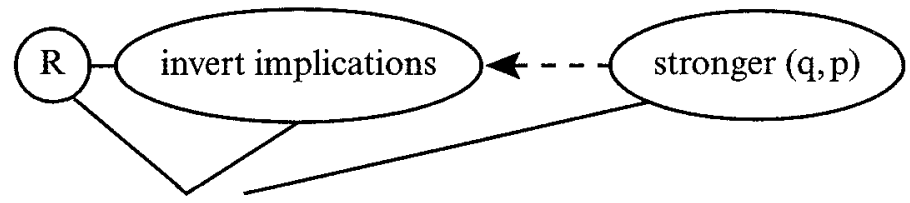

( $[p$ not $r])$ integendeel 'on the contrary' $(q)$

Figure 3. From usage to meaning 2

elements) actually occurs only in negative contexts, that the component parts of the meaning of the expression can become clear (see Figure 3).

However, the development of a semantic analysis in an individual does not undo the initial knowledge that in several instances of use, the expression serves to reinforce the previous assertion, i.e., the usage-based direct link between the expression and the "inference" (although it may be complemented with the possibility of other types of use, derivable from the analyzed meaning in other contexts). There is a good reason for this: the original memory trace provides a shortcut for finding an expression that fits the speaker's communicative purposes without him having to go through all the steps involved in the computation of the inference. Moreover, using memory in this way also helps to guarantee that what the speaker says will look like how others say it, thus optimizing the chance of communicative success. So in fact, it is possible for an individual to use an expression in much the same way as other speakers use it without the "full" development of analytic "insight" into semantic components of the expression; therefore, this stage, as represented in Figure 3, need not be developed in many individuals without dramatic consequences for the way in which the expression is actually used. At the level of the community, when the complex structure is no longer shared by all individuals, its position is weakened while the former inference becomes stronger (Figure 4). Since this non-analytic meaning does not really require a negative context conceptually, it may be extended to non-negative contexts; especially when this becomes part of other speakers' linguistic experience, the meaning may in the end become as represented in Figure 5 in the entire population.

So let us assume that independently of age-something like on the contrary is certainly not acquired early-language users learn the meaning of an element on the basis of its usage, and need not always use the expression on the basis of a more analytic understanding, which they may or may not have acquired. The possible effect when this spreads is language change, as depicted in Figures 1-5. 


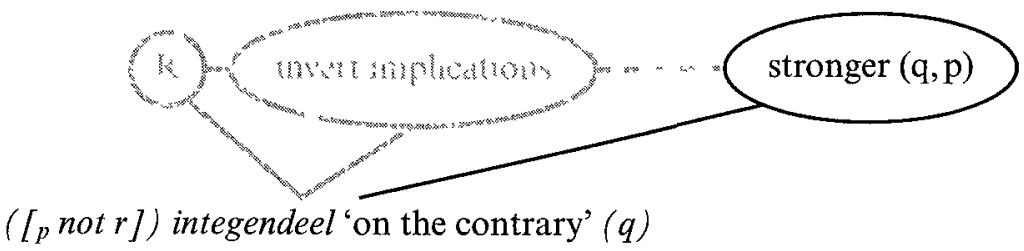

Figure 4, From usage to prototype

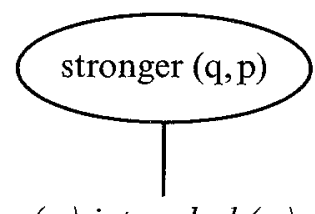

(p) inteendeel ( $q$ )

Figure 5. New meaning from usage

In historical semantics we frequently talk about how inferences become conventional meanings, and Afrikaans inteendeel is yet another case. For example, Traugott (to appear), adopting a suggestion from Levinson (2000), argues that the following presents a very general line of pragmatic/ semantic development: particular inference $>$ generalized inference $>$ coded meaning. However, it is important not to view such a development as a single process that could conceivably take place in an individual, but as a process that is necessarily distributed over many individuals, and that is, paradoxically, dependent on the fact that successful communication need not be based on identity of the individual communicative systems used; rather, individual systems are usage-based, and more than one system is compatible with usage. The nature of individual usage-based processes, going from holistic to possible analytical understanding, thus contributes over time to an effect on the level of the community with the directionality reversed: constructions that used to be composed of different conceptual parts (cf. Figure 1) become holistic units (cf. Figure 5).

In this particular case, the components in the original meaning of the changing expression do not clearly correlate with elements of its form. In other cases, where the form of a construction more clearly consists of multiple parts, not only the meaning of the whole, but also the meanings of the parts may change on the basis of this same kind of mechanism. The case that I want to turn to now is the Dutch version(s) of the by now famous way construction. 


\section{Making ways}

\subsection{Introduction}

With respect to the English way construction, several linguists have demonstrated that the properties of this construction cannot be predicted on the basis of the parts it consists of, plus general rules of grammar. One argument put forward by Goldberg (1996) in defense of the 'autonomy' of the construction, was that although the way construction shares properties with a certain type of resultative construction, it cannot be reduced to the latter (as had been suggested by Marantz), because it differs in all kinds of ways from the general pattern. In this connection, Goldberg makes the point that Dutch does not have the construction:

Finally, Dutch is a language which has fake object resultatives [e.g., He cried his eyes red, He talked himself hoarse, in which the object is not normally an argument of the verb; $-\mathrm{AV}]$, and yet does not have the way construction (Annie Zaenen, p.c.). Because of these various differences, the way construction cannot be directly assimilated to the resultative construction. (Goldberg 1996: 50)

The logic is that if cases of the way construction were simply derivable from rules for fake object resultatives, then any language that has these fake object resultatives should also have examples of the way construction, and Dutch is a counter-example to that prediction. I was somewhat surprised to read this claim about Dutch, because Dutch certainly does have a direct counterpart to the English way construction. However, what I want to show is that this does not at all undermine Goldberg's claim about the independent status of the construction. On the contrary, it will in fact turn out to provide clear support for this claim, and actually even suggest a rather radical interpretation of it.

\subsection{Functional similarities}

Examples of the English construction are (10) and (11), and some examples of the Dutch way construction are in (12), (13) and (14): ${ }^{4}$

(10) Pat pushed her way out of the room.

(11) Volcanic material blasted its way to the surface.

(12) Zo blufte zij zich een weg uit Auschwitz. Thus bluffed she REFL a way out-of Auschwitz 'That was the way she bluffed her way out of Auschwitz.'

(13) Twee bussen boren zich een weg naar het hart van Istanbul. Two buses drill REFL a way to the heart of Istanbul 'Two buses are drilling their way to the heart of Istanbul.' 
De priesters wurmen zich een weg door de gelovigen. The priests squeeze REFL a way through the faithful 'The priests squeeze their way through the faithful.'

The similarities are obvious: there is a constant lexical element weg, a variety of verbs indicating the means by which a path is created, and prepositional phrases specifying the path being traveled. The lexical meanings of the verbs in the construction do not have to contain a component of movement, but the referents of their subjects all move, clearly because of the meaning of the construction itself--all very good reasons to consider this pattern the Dutch analog of the way construction. However, the syntax is clearly a respect in which the constructions in the two languages are different. Whereas the relationship between the subject and the created way is marked by a possessive determiner in English, it is marked with a light reffexive ( $z i c h)$ in indirect object position in Dutch. The patterns for the English and Dutch constructions may be given as in (15) and (16):

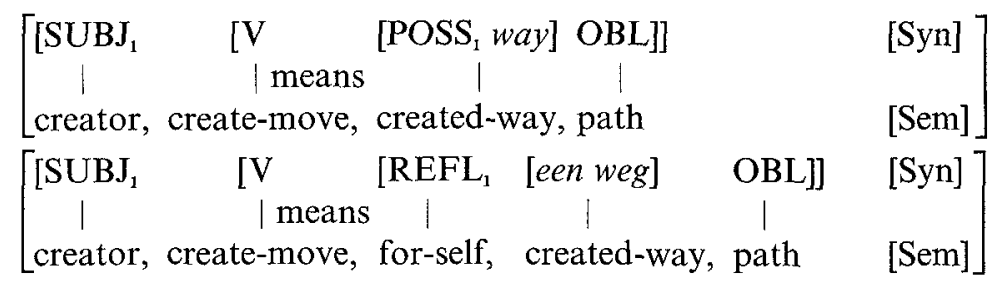

Another difference concerns the verbs used. Table 1 lists the verbs occurring in this construction in the corpus investigated ${ }^{4}$.

The pattern should be obvious: half of the time there is a verb that clearly contributes its lexical meaning to the interpretation of the sentence, as the means by which the way is made, but in the other half just a single verb occurs, namely banen. This is clearly the default verb for the construction, but what is this verb's role in the language, what does it mean? When asked, speakers of Dutch tend to answer: "to make, namely a way". The point is that it only occurs in this kind of construction; it does not really have a meaning independently of this kind of combination. If one tries to describe its meaning, then one essentially ends up with something very similar to the meaning of the entire construction.

It has not always been like this. The verb banen used to have an independent meaning, more or less 'to level, to make a surface smooth', so here we have a change over time in the relationships between parts and wholes (cf. section 3.4). However, let me already point out now that 


\section{Making ways}

\subsection{Introduction}

With respect to the English way construction, several linguists have demonstrated that the properties of this construction cannot be predicted on the basis of the parts it consists of, plus general rules of grammar. One argument put forward by Goldberg (1996) in defense of the 'autonomy' of the construction, was that although the way construction shares properties with a certain type of resultative construction, it cannot be reduced to the latter (as had been suggested by Marantz), because it differs in all kinds of ways from the general pattern. In this connection, Goldberg makes the point that Dutch does not have the construction:

Finally, Dutch is a language which has fake object resultatives [e.g., He cried his eyes red, He talked himself hoarse, in which the object is not normally an argument of the verb; -AV], and yet does not have the way construction (Annie Zaenen, p.c.). Because of these various differences, the way construction cannot be directly assimilated to the resultative construction. (Goldberg 1996: 50)

The logic is that if cases of the way construction were simply derivable from rules for fake object resultatives, then any language that has these fake object resultatives should also have examples of the way construction, and Dutch is a counter-example to that prediction. I was somewhat surprised to read this claim about Dutch, because Dutch certainly does have a direct counterpart to the English way construction. However, what I want to show is that this does not at all undermine Goldberg's claim about the independent status of the construction. On the contrary, it will in fact turn out to provide clear support for this claim, and actually even suggest a rather radical interpretation of it.

\subsection{Functional similarities}

Examples of the English construction are (10) and (11), and some examples of the Dutch way construction are in (12), (13) and (14): ${ }^{4}$

(10) Pat pushed her way out of the room.

(11) Volcanic material blasted its way to the surface.

(12) Zo blufte zij zich een weg uit Auschwitz. Thus bluffed she REFL a way out-of Auschwitz 'That was the way she bluffed her way out of Auschwitz.'

(13) Twee bussen boren zich een weg naar het hart van Istanbul. Two buses drill REFL a way to the heart of Istanbul 'Two buses are drilling their way to the heart of Istanbul.' 
De priesters wurmen zich een weg door de gelovigen.

The priests squeeze REFL a way through the faithful

'The priests squeeze their way through the faithful.'

The similarities are obvious: there is a constant lexical element weg, a variety of verbs indicating the means by which a path is created, and prepositional phrases specifying the path being traveled. The lexical meanings of the verbs in the construction do not have to contain a component of movement, but the referents of their subjects all move, clearly because of the meaning of the construction itself - all very good reasons to consider this pattern the Dutch analog of the way construction. However, the syntax is clearly a respect in which the constructions in the two languages are different. Whereas the relationship between the subject and the created way is marked by a possessive determiner in English, it is marked with a light reflexive (zich) in indirect object position in Dutch. The patterns for the English and Dutch constructions may be given as in (15) and (16):
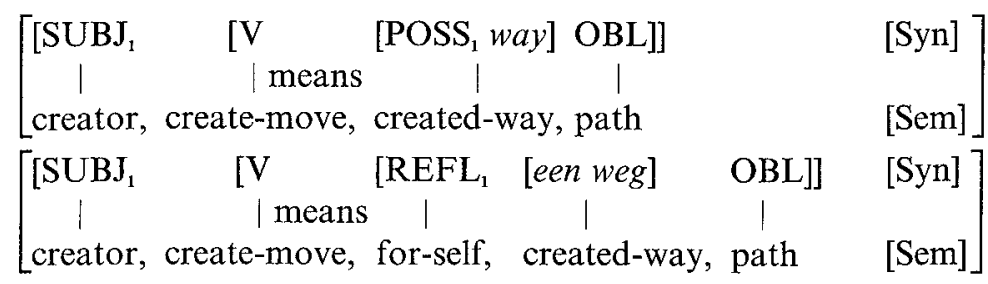

Another difference concerns the verbs used. Table 1 lists the verbs occurring in this construction in the corpus investigated ${ }^{4}$.

The pattern should be obvious: half of the time there is a verb that clearly contributes its lexical meaning to the interpretation of the sentence, as the means by which the way is made, but in the other half just a single verb occurs, namely banen. This is clearly the default verb for the construction, but what is this verb's role in the language, what does it mean? When asked, speakers of Dutch tend to answer: "to make, namely a way". The point is that it only occurs in this kind of construction; it does not really have a meaning independently of this kind of combination. If one tries to describe its meaning, then one essentially ends up with something very similar to the meaning of the entire construction.

It has not always been like this. The verb banen used to have an independent meaning, more or less 'to level, to make a surface smooth', so here we have a change over time in the relationships between parts and wholes (cf. section 3.4). However, let me already point out now that 
Table 1. Verbs used in the Dutch 'way' construction (Volkskrant 1995)

\begin{tabular}{lll}
\hline Tokens/verb & Verbs & Total number \\
\hline 1 & beitelen 'chisel', boren 'drill', graven 'dig', knagen 'gnaw', & 8 \\
$\quad$ kronkelen 'twist', ploegen 'plough', slaan 'hit', & \\
$\quad$ wurmen 'wriggle' & 6 \\
2 & bluffen 'bluff', vreten 'eat, gnaw', zoeken 'search' & 3 \\
3 & snijden 'cut' & 5 \\
5 & vechten 'fight' & 23 \\
23 & banen (no independent meaning) \\
\hline
\end{tabular}

functionally the difference between Dutch and English is not as big as it may seem: both languages have a default verb as a way of realizing the construction while leaving the means of creation or movement unspecified. They only use different resources for doing this: English uses a general verb, to make, the meaning of which is basically already part of the meaning of the construction, while Dutch employs a verb that virtually means the same as the construction. Speakers of both languages have one specific instance of the construction stored in memory as its prototype; in this respect, the structure of their linguistic knowledge is highly comparable.

Another point of similarity between English and Dutch concerns the occurrence of prepositions and adverbs in the oblique phrase (OBL) slot indicating the path being created and traveled. As can already be seen from the examples in (10)-(14), the adjuncts in this position in both languages can mark a direction and/or parts (beginning, ends, or segments) of the path involved. Table 2 lists the prepositions and adverbs used in the present corpus. ${ }^{5}$

The preposition door 'through', occurs in more than half of the cases. In general, an oblique phrase is present very frequently. Normally, adjunct phrases are considered optional, but in this case they are part of the conventional schema. ${ }^{6}$ Combining the evidence from Tables 1 and 2, there is reason to assume that speakers of Dutch have stored in their memory both the highly specific schema zich een weg banen door $X$ (with both the verb and the path-marker lexically specified), as well as the more general, superordinate schema zich een weg $+V+O B L$, with the specific pattern being the prototype of the general schema. In view of the relatively high frequency of the combination zich een weg terug vechten 'fight one's way back', one might want to suggest that this is also stored as a specific pattern, though not as well entrenched as the prototype. ${ }^{7}$ Graphically this is shown in Figure 6. 


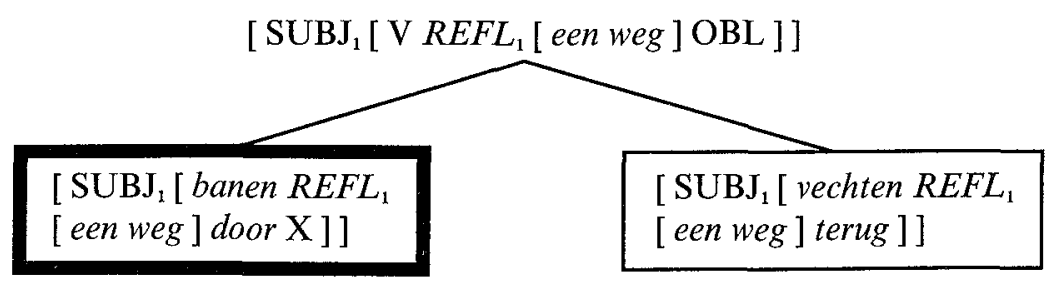

Figure 6 Dutch way construction network (lower part)

Table 2 OBL-markers used in the Dutch way construction (Volkskrant 1995)

\begin{tabular}{lll}
\hline Tokens/marker & Preposition or adverb & Total number \\
\hline & Absent & 3 \\
1 & in 'in(to)', langs 'alongside, over 'over', & 5 \\
& tot 'till', utt 'out of' & \\
2 & tussen 'between' & 2 \\
3 & terug 'back'* & 3 \\
9 & naas 'to' & 9 \\
26 & door 'through' & 26 \\
\hline
\end{tabular}

*All three cooccurring with the verb vechten 'to fight'

Instantiations of the construction as in example (12) are certainly not stored independently Rather, they are licensed by the general schema, or formed as analogs to the stored patterns-which may in fact well be considered two aspects of what is essentially a single process (Langacker $2000 \quad 12-13)$

\section{Syntactlc differences}

Having considered similarities between the Dutch and English patterns, let us now return to the issue of the difference in syntax As can be seen from (15), the English way construction is realized as a transitive, two participant clause (with a moving subject, a created path as the object, and an oblique phrase specifying the path) Thus, while make one's way through $X$ is a specific case of a more general pattern $V$-one's way-OBL, the latter in turn constitutes a subordinate pattern of the even more general pattern $V-O B J-(\mathrm{Compl})$, thus a somewhat extended network of constructions can be represented schematically as in Figure 7

The most schematic construction in Figure 7 is also instantiated by fake-object resultatives ( $\mathrm{cf}$ the quotation from Goldberg 1996 in section 21 ) such as He cried his eyes red, although not all of the properties of 


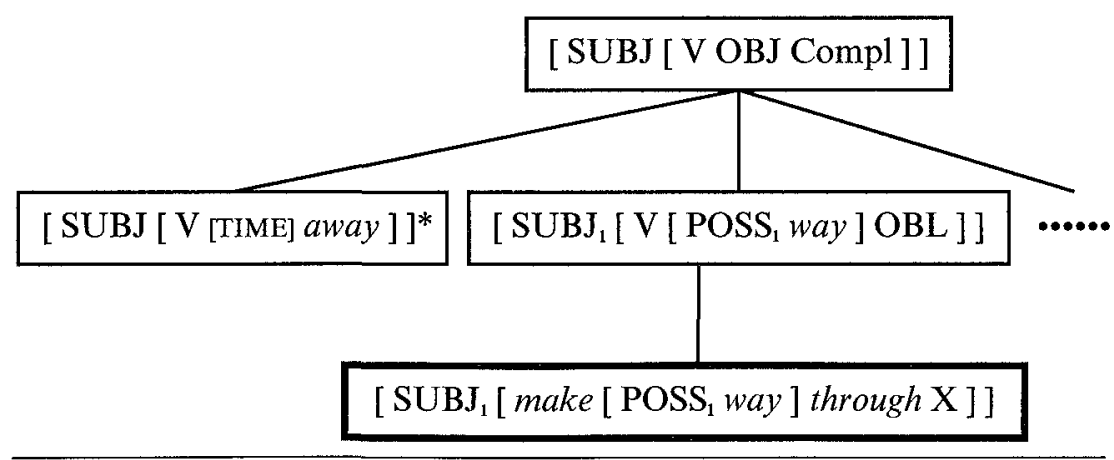

* The so-called TIME-away construction (Jackendoff 1997); cf. section 4.2.

F1gure 7 Extended partial network for English 'way' construction

the way construction can be predicted on the basis of the general pattern for resultatives, the way construction does seem to inherit properties of the superordinate construction: a path is created, and movement results in a new location of the subject, which is specified by the oblique phrase.

Now notice that the Dutch construction, as shown in (16), is realized as a ditransitive, three-participant clause, with a reflexive pronoun as the indirect, benefactive object, and the indefinite phrase een weg as the direct object. Thus as far as syntactic shape goes, the Dutch construction is certainly not an instance of a resultative construction. Rather, it seems to be an instance of a benefactive construction, basically saying that someone makes himself a path through some obstacles. One might therefore want to put the Dutch way construction in the same category as other ditransitive constructions, the prototype of which involves situations of transfer (with verbs like give, pay, promise), and propose that an extended network for the Dutch way construction should be represented as in Figure 8.

As a consequence, the constructions would occupy quite different positions in the "grammatical space" of these two languages. If the relation of a construction to superordinate patterns (i.e., the answer to the question: "Of which general pattern is this construction an instantiation?") were a substantial determinant of the nature of a construction, then the Dutch and the English way constructions should actually not be very similar to each other. So the question is: Should the network in Figure 8 indeed be considered adequate for Dutch?

At least in some very important sense, the answer must clearly be "No". The reason is that this kind of benefactive construction is actually not a 


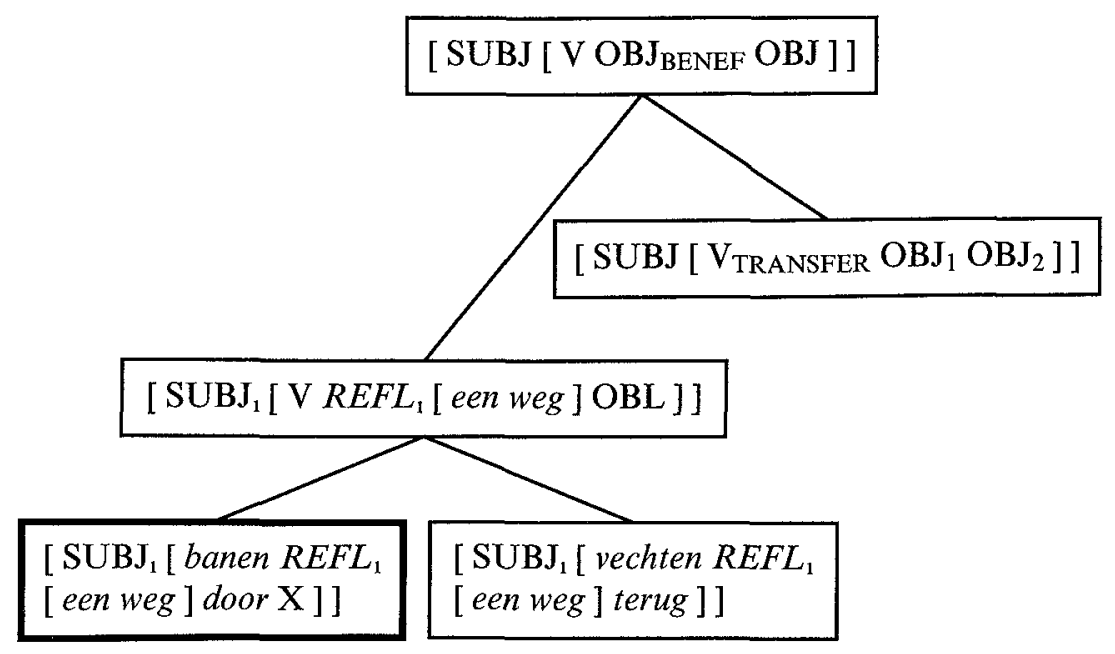

Figure 8 Hypothetical extended network for Dutch 'way' construction

general grammatical pattern in Standard Dutch, unlike the superordinate resultative construction in the English network in Figure 7.

Speakers of Dutch, unlike speakers of English, do not say things like (17), i.e., the ditransitive pattern is not used to express this type of event; instead, they say things like (19), with the benefactive expressed in a prepositional phrase.

(17) *Jan maakte haar een boterham

(18) John made her a sandwich

(19) Jan maakte een boterham voor haar John made a sandwich for her 'John made her a sandwich.'

The productive use of the ditransitive pattern in Dutch seems to be restricted to events in which the referent of the direct object is not being created. ${ }^{8}$ So paradoxically, English seems to have a relatively productive schema for benefactive constructions, but its way construction is not an instance of it (rather, it seems to be a specific case of a resultative pattern), while Dutch does not have a productive benefactive construction, although its way construction does seem to instantiate it. We have to exclude it from the network of Dutch constructions, and replace Figure 8 by Figure 9: the network of more and less specific way constructions actually constitutes a kind of island in the whole of the grammar. 
[ SUBJ [ $\left.\mathrm{V}_{\text {TRANSFER }} \mathrm{OBJ}_{1} \mathrm{OBJ}_{2}\right]$ ]

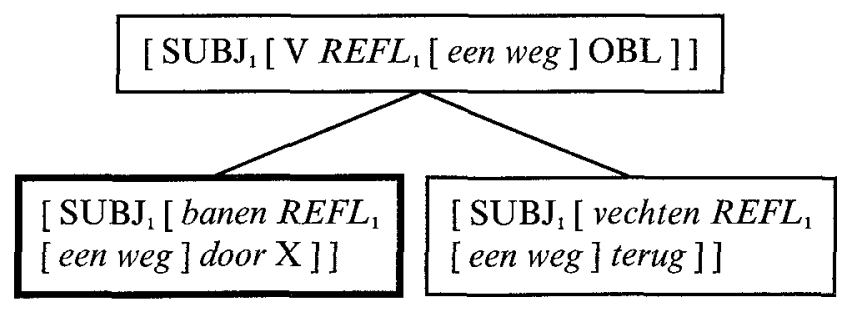

F1gure 9 The Dutch 'way' construction ssland

This is why the existence of a way construction in Dutch does not in fact undermine the claim that it must be separately stored in memory, but actually reinforces it. It also has the consequence that on the level of the patterns that apparently do matter most, we can maintain the position that the difference between the English and Dutch constructions is not very big: they both line up the relevant concepts with formal elements in almost the same way.

The fact that speakers do not use the way construction in Dutch as evidence for the existence of a more general rule, shows that it is really quite normal that a pattern of usage is represented as a whole, including internal structure, without this internal structure being analyzable as parts that have been put together. ${ }^{9}$ But it would be wrong to conclude from this that internal structure is irrelevant to the function of a construction, and it is worthwhile to elaborate this point somewhat further.

According to Goldberg $(1995,1996)$ and others, at least some speakers of English can use the way construction in such a way that the verb does not indicate the means by which a path was created, but simply some activity accompanying the movement along a path. This usage does not exist at all for the Dutch case. Thus (20) is OK for (at least some) speakers of English, with no need to impose a reading of "removing obstacles by whistling," but (21) in Dutch can only mean that he created a way to the front door by whistling, and hence it is very strange:

(20) He whistled his way to the front door.

(21) ??Hij floot zich een weg naar de voordeur $\mathrm{He}$ whistled REFL a way to the front-door 
Israel (1996) relates this to two historical sources of the English way construction; two typical instantiations of these original sources are He paved his way and He went his way. At first, the sets of verbs occurring in each pattern were restricted so that they did not overlap, but over time they expanded and became partly overlapping. Given the linear parallelism, it is not hard to see that with this expansion of the paradigms, the overlap of the constructions becomes sufficiently big for speakers to start treating them as variants of each other. In Dutch, as we have seen, the pattern used for the meaning "create a path" happened to be the one with a reflexive indirect object, not a possessive direct object. There are also expressions for "going one's way" or "continuing on one's way", but they are structurally more different from the source of the way construction than in English:
Hij ging zijns weegs.
He went his + GEN way + GEN
'He went his way.'
Zij vervolgde haar weg.
She continued her way
'She continued on her way.'

These exhibit a syntagmatic pattern similar to what is now 'the' English way construction, i.e., with a possessive-marked direct object, not a reflexive indirect object. It seems highly plausible that this structural difference has been an obstacle blocking the two patterns from merging, and thus contributes to an explanation of the difference between modern English and modern Dutch, i.e., the fact that the modern Dutch construction does not have the possibility of an 'accompanying activity' reading. ${ }^{10}$

Another relevant aspect of the syntactic structure of the Dutch way construction is that it also sets it apart from one other type of pattern in which the verb banen can appear; this is exemplified in (24) through (26).

(24) Met deze grondwetswijziging heeft hij de weg naar de troon gebaand voor zijn dochter.

'With this constitutional amendment he smoothed/paved the way to the throne for his daughter.'

(25) Haar strijd baande de weg voor legalisatie van abortus.

'Her struggle smoothed/paved the way for legalization of abortion.'

(26) Dit koor baande de weg voor kleinere ensembles.

'This choir smoothed/paved the way for smaller ensembles.'

These sentences also contain the noun weg besides banen. The biggest difference seems to be that there is no reflexive indirect object in these 
cases, but a prepositional phrase with voor 'for'. The question is: Is this simply a non-reflexive variant of the other construction, with someone else moving than the subject itself? Should we represent it as in (27), i.e., parallel to (16) with the only difference that the creator and the mover are not the same? ${ }^{11}$

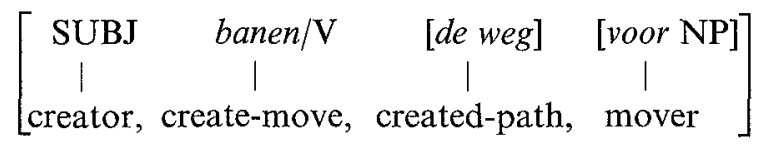

When we look at specific examples, it becomes clear that the answer to this question has to be "No".

(28) Daarmee opent hij de weg naar machtsmisbruik.

'With that he is opening the way to abuse of power.'

(29) Zijn concessie maakte de weg vrij voor ondertekening van het akkoord. 'His concession cleared the way [lit.: 'made the way free'] for the treaty to be signed.'

(30) Deze uitspraak effent de weg voor de scheiding van de carrieres van rechters en aanklagers.

'This decision levels/paves the way for the separation of the careers of judges and prosecutors.'

(31) Hij liet de weg voor onderhandelingen open.

'He left the way for negotiations open.'

(32) De hoge opkomst blokkeerde tevens de weg voor diverse andere FNkopstukken.

'The large turnout also blocked the way for several other FN top people.'

The first difference is not only that the first construction ("construction A") contains a reflexive, and the second one ("construction B") a forphrase, but also that it is not completely obvious that reference to a beneficiary is obligatory in construction B: (28) does not contain one and the for-phrases in (29) and (31) seem to mention endpoints of the path rather than beneficiaries (I will return to this below). Furthermore, the noun weg is obligatorily indefinite in construction A, and obligatorily definite in construction B. ${ }^{12}$ Most importantly, the verbs occurring in construction $A$ are activity verbs, indicating the method of creation and/or traveling of the relevant path, while the verbs in construction B constitute a more specific, and also more restricted set: transitive verbs and verbal expressions meaning "to open" (28), "to clear" (29), "to level" (30), "to leave open" (31) and "to block" (32). What these have in common is that they all evoke the notion of a barrier (more specifically, its [non]insertion 
or [non]removal); they denote elementary dimensions in the conceptual domain of force-dynamics. The intransitive verbs indicating the means by which the path is created, which are completely appropriate in construction $\mathrm{A}$, are excluded in construction $\mathrm{B}$ :

??Zo vocht/blufte hij de weg voor/naar de overwinning Thus fought/bluffed he the way for/to the victory

The association with force-dynamics verbs points to a crucial semantic distinction between the two constructions. Construction B evokes the idea of a possible route and a barrier that potentially prevents a goal being reached, but unlike construction $\mathrm{A}$ it does not necessarily evoke the idea that the goal is ultimately reached. Notice that the same holds for the English expression to pave the way; consider the following sentence from the table of contents of vol. 285, number 1 of Scientific American (July 2001):

(34) Halting photons paves the way for quantum computing and tabletop black holes.

Certainly the goals of quantum computers and tabletop black holes are not realized in the achievement of halting photons by itself.

Many instances of use of construction B in Dutch ([28] and [31] are clear examples) do not entail that the barrier is removed and the goal reached. The fact that this interpretation is obligatory in construction A explains why sentences like (35) and (36) are strange; the semantic constraints imposed by the construction (a path is created, and the goal is reached) conflict with those imposed by the verbs:

??Hij liet zich een weg vrij naar een andere baan
He let REFL a way free to an other job
??Zo blokkeer je je een weg naar de top
Thus block you you a way to the top

The meaning of "to leave free" presupposes that the path is already there, and "to block" denotes an action with an effect that is the counterpart of creating a path.

Finally, it should be noted that construction A obligatorily contains both a specification of the beneficiary (in the reflexive) and some specification of the path being traveled, while almost all of the actual instances of construction B contain only one prepositional phrase, denoting either the beneficiary or the path being traveled: examples like (24) are very rare. One might suggest that the distinction is sometimes not even obvious; for example, (26) may be understood in such a way that "smaller ensembles" could be formed as a result of the success of the larger 
choir (goal-reading), or that the chances of pre-existent smaller ensembles improved (beneficiary-reading). The two types of roles have the notion of "goal" in common, and this may be all that is required by the construction, as represented in (37).

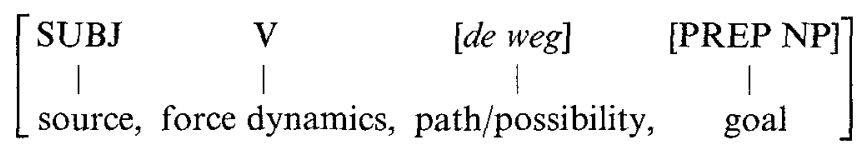

Besides these differences, there is, of course, still an important similarity between the two constructions, one that sets them apart together from other constructions in the language. They both contain the lexically specified element weg and in their prototypical instantiations the verb banen; these formal elements are furthermore associated with the semantic component OBSTACLE in the meaning of both constructions. But the similarity is precisely that: similarity, not a more abstract category from which the two specific cases would be derivable as instantiations. I suggest that it can be useful to make this difference explicit in the method of representation of relations between constructions. Rather than representing similarity as a less-entrenched category (indicated by the difference in thickness of the boxes; cf. Langacker 2000: 13/4) as in Figure 10, I would like to represent it by a link between the elements themselves which exhibit the similarity, as in Figure 11. ${ }^{13}$

The crucial difference is that the notation of Figure 11 more explicitly indicates that there is not an independent node in the network than can conventionally serve as a template that allows variable elements to be put into open slots. In Figure 10 this would require a separate stipulation about the top node in that piece of the network. A further advantage of marking this distinction is that it also provides a way of conceiving of the relationship between the way construction in Dutch and the general ditransitive pattern. A possible objection against the representation in Figure 9 is that it does not represent any connection at all between the way construction in Dutch and other ditransitive constructions. We can now say that this connection is also one of similarity, not between lexical elements, but between the combinatorial patterns. ${ }^{14}$ Combining a number of the constructions discussed including relations of similarity we get the representation in Figure 12.

Replacing some categorizing relationships in taxonomies of constructions by similarity links leads to a rather loose conception of the organization of grammatical knowledge. It does not really consist of a tightly integrated network where ultimately every construction has a traceable categorizing relation with every other one. It is more like a loose set of islands of constructions, albeit with some similarities. To borrow a 


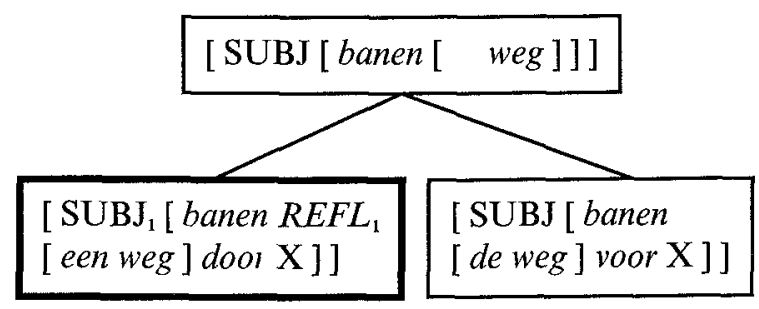

Figure 10 Similanty as a category in a network

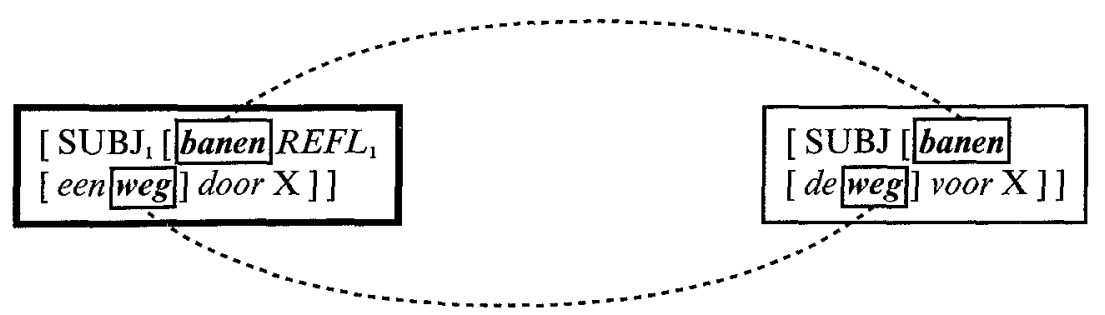

Figure 11 Simularty as link between elements

metaphor from Croft (2000) languages are more like plants, as relatively loosely structured organisms, than like animals, which are (even) more complex systems, and where the relations between the parts are much more 'finely balanced' Still, similarities may have an effect on large portions of a grammar and on specific patterns, as they strengthen the representation of the related patterns, even if they do not have the status of a rule telling the speaker how to bulld such structures It seems reasonable to assume that similarities between two different stored patterns, especially if such similarities are both formal and semantic (1 e, symbolic), increase the strength of the representation of both patterns This may well provide the basis for an answer to the question why different grammatical constructions in a language do not have completely random overall structures (although the variation here is still definitely larger than what one might expect on a rule-based account)

\section{Diachronic developments}

\section{From parts to whole}

In present day Dutch, then, we have two independently represented way constructions, with some connections between features of meaning as well 


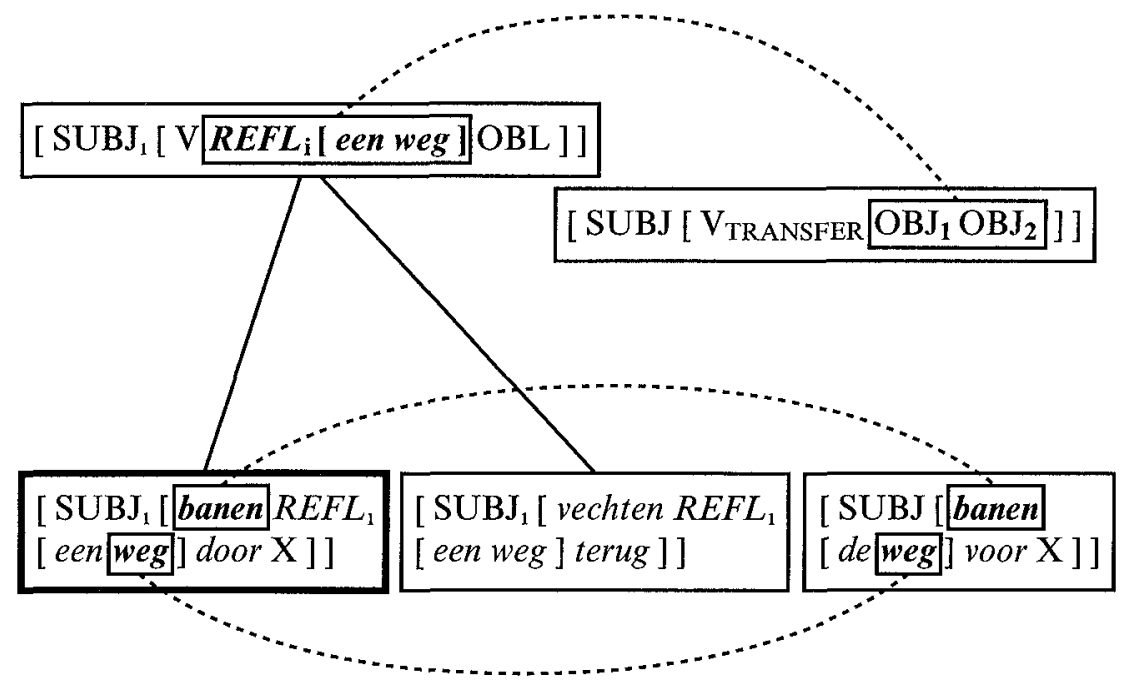

F1gure 12 Network with some categorizing and simlarty links

as form. How has this situation come about? Several details are still unclear, especially about the origin of the construction and the reflexive in it, but there is sufficient evidence to present some general outlines. ${ }^{15} \mathrm{As}$ a start, (38) shows that banen could be used as an independent verb, meaning "to flatten" or "to level" in the early 17 th century.

(38) Rasch Zuyde Winden baant nu d'heuvelighe duynen, en slecht het mulle zandt, en blaast de dorre kruynen ter daalwaarts in.

'Quickly Southern Winds, now flatten the hilly dunes, and level the shifting sand, and blow the barren tops down into the valleys.'

But already at this stage, the combination with weg is quite frequent, although basically free. Examples (39) through (41) show variable combinations of reflexive and non-reflexive, dative, definiteness and indefiniteness, thus suggesting the possibility of freely combining these elements into larger wholes.

(39) Turcken en Arabianen Sullen noyt goe weghen banen

Turks and Arabs shall never good ways smooth/pave Voor den Christen

for the Christian

'Turks and Arabs will never pave good ways for the Christian.' 
(40) Koomt gy my een weg tot grooter droefheid baanen? Cometh thou me a way to greater sorrow pave 'Are you coming to pave me a way to greater sorrow?' [ \pm 1720$]$

(41) wilt ghy hebben een ... gesegent Huwelijck, 'if you want to have a blessed marriage,' gy en moet $u$ selven daer toe den wegh niet banen, thou NEG must you self + DAT there to the + ACC way not pave 'you must not pave yourself the way towards it' met vlechtinge en optoyinge des hayrs, met een naeckten hals ... Maer ghy moet ...

'with tresses and adornments of the hair, with a plunging neckline ... But you must ...

Example (41) is interesting semantically, in that it shows that at this point in time, the construction did not necessarily convey the meaning that the goal was actually reached, that there was movement along the created path. The context makes it clear that what is meant is that one should not attempt to reach a goal in this way, which in 1634 could apparently be conveyed by the construction as such. So this shows that the meaning of opening a possibility is the oldest one, in accordance with the original meaning of banen, making a path smooth and thus easier to travel, but not necessarily traveled.

The movement component in the meaning seems to be a relatively late development. In the material collected in Kramer (2002), the variety of verbs that appears in the construction besides banen is at first essentially limited to force-dynamics related ones, such as open in (42).

... waer omtrent hy, naer een bloedigh treffen met eenige Franssen ...

'... where he, after a bloody battle with some Frenchmen ...'

zich met geweld een wegh opende

REFL with violence a way opened

'opened himself a way with force'

(43) Dat hij door bloed en neerlagen der vijanden,

'That he, through blood and defeats of enemies,'

zich een weg ten Hemel open gestoten heeft.

REFL a way towards Heaven open thrust has

'pushed himself a way open to Heaven.'

In (43) an action verb, stoten 'to thrust', is used; however, not just on its own, but in combination with the predicative adjective open, and this seems to be typical at this stage. What these cases show is that the idea of the path being created rather than just made easier to travel, is 
probably already conventionalized at this point, as is also remarked in the WNT - the 'Dutch Oxford English Dictionary'-on banen:

The expression de (een) weg banen, which properly meant "make the (already existing) road smooth, passable", was later interpreted in the sense of "construct a (so far not existing) road, make a passage, etc.; with writers it approaches figurative use. [My translation]

So what has happened here historically is the following: speakers had been using the combination of words weg banen "to level a road, making it easier to travel" to convey messages of the type "to create a possibility to reach a goal", and then the "create" component of this message became a conventional meaning of banen.

The starting point of the development can be depicted as in Figure 13 (the notation is adopted from Geeraerts 1995).

The meaning of banen and weg are combined to give the meaning "path-leveling", which is metaphorically extended to "enhancing the chances, creating the possibility to reach some goal"; the elements of the metaphorical interpretation are also metaphorically related to the elements of the literal interpretation: the possibilities are linked to weg 'way' and the action of creating to banen 'to level'. ${ }^{16}$ In the course of the development then, what was originally a contextually determined, extended interpretation of the conventional meaning "to level a path," became directly associated with the formal combination weg-banen itself; it was no longer derived from the original conventional meaning, which actually disappeared, resulting in the present situation as represented in Figure 14: there is a constructional idiom, a unit with the conventional meaning "to create a possibility/remove an obstacle", with the conceptual elements "possibility" and "creating" still linked to the formal ones banen and weg, respectively.

This picture closely resembles the semantic development of Afrikaans inteendeel discussed in section 1 (the most important difference being that in the case of inteendeel, the conceptual components did not correspond to formal elements). In fact, notice that just as in the case of the change of Afrikaans inteendeel from Dutch integendeel, the development of a contextual interpretation becoming a conventional meaning cannot represent a process completely within individuals; rather it must have been distributed over many, for exactly the same reason: If the interpretation "create possibility" would always be derived inferentially, then the meaning elements on which it is based ("level a path") cannot disappear without the inference itself disappearing, while we have just seen again that the inference has become the meaning. Thus the same conclusion must be drawn, namely that at least for a substantial number 


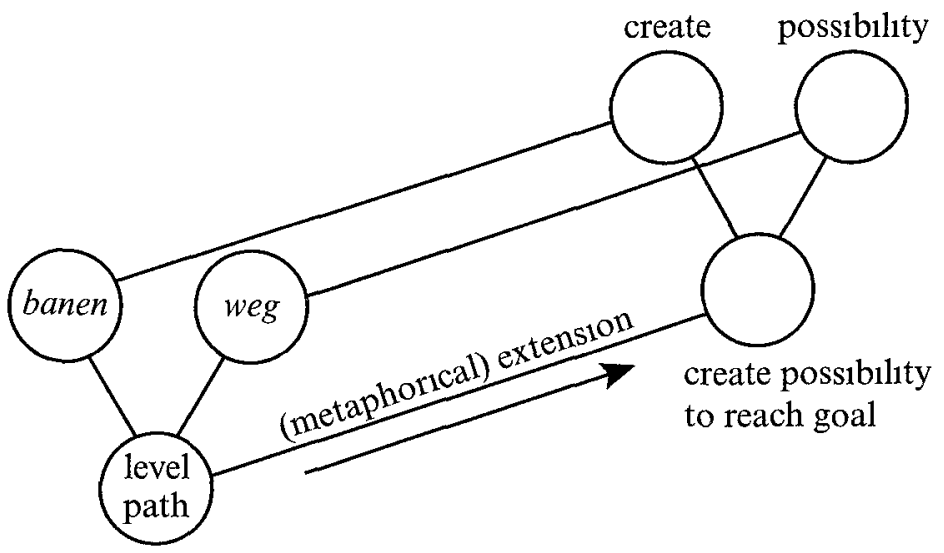

Figure 13 From meaning to usage pismatic model for weg banen

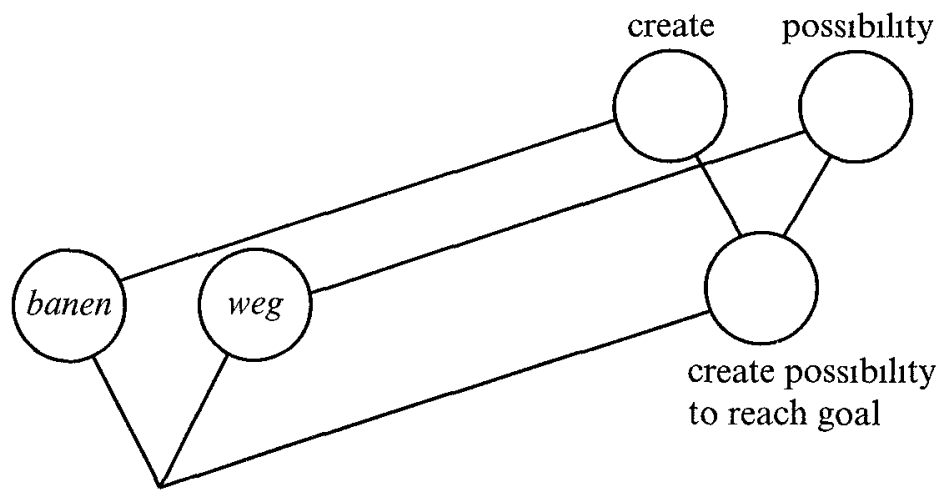

Figure 14 From usage to meaning in weg tbanen

of speakers (after the 'invention' of this type of usage), this idea must have had a direct connection to the expression in order to allow it to survive when the original meaning components were lost The directness of such a connection is what one may expect in the usage-based conception, where analytic, abstract understanding arises out of the accumulation of linguistic experience

In other words in many individual speakers, the development of the meaning of the combination weg + banen went from the situation depicted in Figure 14 to the situation depicted in Figure 13 as their linguistic experience with the elements banen and weg increased, also in a situation when on the level of the language community the meaning of banen and weg is described adequately by Figure 13 itself But again, learning 
the analysis of the whole does not undo the original link between the entire expression and its holistic interpretation, and in fact allows some individuals not to acquire an analytic understanding at all and still be able to use the expression adequately in many relevant communicative situations. To the degree that (a) the number of speakers for which the latter holds increases, and (b) the portion of this particular type of usage events grows (two developments that reinforce each other), the linguistic knowledge of the whole language community will ultimately be as depicted in Figure 14. The effect is, then, that the development on the level of the community as a whole can be described as going from Figure 13 to Figure 14, as a consequence of the reverse, usage-based development taking place in individuals.

\subsubsection{From whole to parts}

Let us now turn to the question where the semantic difference between the two modern Dutch way constructions comes from. Similar mechanisms are involved as we discussed in the previous section, but an additional point here is that a relationship in a construction between semantic components and formal elements provides possibilities for variation and thus change not present in situations where such a relationship is lacking, as in Afrikaans inteendeel. Another reason why it is interesting to look at this specific issue in some detail, is that it exemplifies another recurring pattern of semantic change, that of possibility to causation (cf. section 4.1), in the context of a construction.

As we have seen at the beginning of section 3.4.1, in the 17th century the combination of banen with a dative, reflexive or non-reflexive indirect object was basically free, with no obvious systematic difference between one choice or the other. So what could have provided the basis for the combination of weg + banen with a reflexive benefactive (zich) to develop into an independent construction? Again, this seems to be an inference originally derivable from the combined conventional meanings, which over time got systematically associated with the expression as a whole.

When a path is paved or created for oneself (making motion possible), the message conveyed by the sentence as a whole will most of the time include the idea that the (implicit or explicit) goal is reached, and thus that movement takes place (caused motion). Creating a path for one's own benefit and then not traveling it, or metaphorically, creating an opportunity for oneself and then not using it, does not make much sense. This inference will not arise so easily, thus less frequently, with nonreflexive benefactives, simply because reaching the goal or not depends, to a considerable extent, on the benefactive participant (the potential mover) himself. Thus in the specific combination with a reflexive benefactive, 


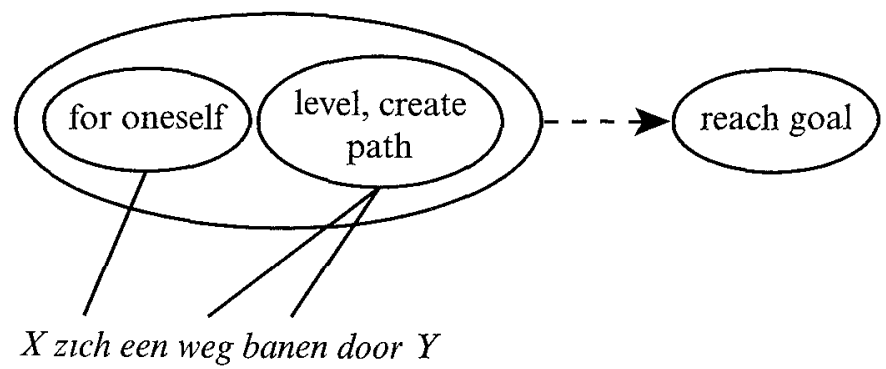

Figure 15 Reflexive path-creation movement inferred

many actual cases of use will convey movement along a path, as indicated in Figure 15

In the present language this usage has become obligatory to the point that it is no longer possible to use a verb of "opening" or "leaving free" besides banen in this frame, and from this fact we must once again conclude that language users have stored the association of this specific pattern with this specific function as they encountered it in usage, not analyzing it into the parts that previous users had done, and that this stored association has spread across the community

When the 1dea of reaching a certain end-state (caused motion as opposed to just possible motion) has become associated with the reflexive pattern as a whole, this aspect of the interpretation is no longer dependent on the lexical meaning of the verb This is what must have paved the way for verbs indicating the means of creating the path, to come to be used in the slot formerly only occupied by force-dynamic-related verbs, especially banen The first uses of this kind must have been creative analogical extensions, made possible as the fixed elements REFL een weg were sufficient to 'activate' the entire template This use is so frequent now that speakers, encountering it in usage, generalize it to a property of the schema as such, producing the schematic representation in (16) Thus at least this particular part of the reflexive way construction has over time acquired a new function, which we can represent as in Figure 16

The result is two distinct populations of utterances where there used to be only one, in such a way that elements essential to one, such as the reflexive pronoun, cannot be part of the other and vice versa, $1 \mathrm{e}$, a process essentrally analogous to the separation of a population of one biological species into two new ones It is this separation that is reflected in the grammar as the distinction between two constructions, which bear similarities to each other but nevertheless have independent memory representations 


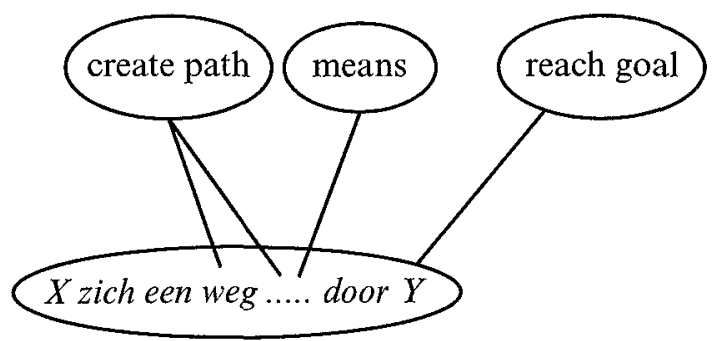

Figure 16. Reflexive way-construction: movement as construction meaning, slot for verbs indicating means of path-creation

\section{Two extensions}

I will now turn briefly to two more illustrations of the ideas developed in this paper. The first one points to the possibility of similarities between changes in different parts of the grammar, under the influence of the same kind of mechanisms. The second demonstrates that even the grammars of closely related languages, in this case Dutch and English, may have the same kind of work done in very different parts of the grammar, namely morphology and syntax, while it is still true that their behavior is similar, again under the influence of the same kind of processes.

\subsection{Causatives}

We have seen that the development of the reflexive way construction in Dutch involved a change from creating a possibility to achieving a result, in a highly specific context. This may provide a promising model for a solution to a problem in the history of regular causative constructions in Dutch. ${ }^{17}$ In Dutch, as in other languages, the auxiliary laten which originally meant "not intervene, to permit", has developed into the most common marker of causative constructions (cf. Verhagen and Kemmer 1997 for Modern Standard Dutch; Verhagen 2000a for the recent history). In principle, a step-by-step-conceptual connection between not intervening on the one hand and causation on the other is not so hard to formulate in force-dynamics terms, and this has been used in several analyses. An example is in the following quote from a Dutch historical linguist:

"From the inactive laten ('not acting'), the various meanings have arisen which we still know: $\Rightarrow$ 'not prevent' $\Rightarrow$ 'tolerate/permit/' $\Rightarrow$ 'allow/grant' $\Rightarrow$ 'effectuate'. The transitions are smooth. If one lets something happen by not interfering, then in some sense one is also active; ...." (Duinhoven 1997: 484. My translation). 
But there is actually a serious problem with it. If the development only consisted of these conceptual steps, then what we should expect is that the fully causative readings arise only as the most recent development, and this is not really what we find. Instead, we already find instances of use that appear to be fully causative in early stages of the development, but less frequently than in the modern language. An example is (44), from a 13th century zoological treatise: ${ }^{18}$

(44) [Give the sick bird some drugs, and then]

settene dart es sonder lecht/ende latene enen

put-it + ACC there-it is without light / and let-it $+\mathrm{ACC}$ one $+\mathrm{OBL}$

dach uasten

day fast

'put it in a dark place, and let it fast for one day.'

Here we certainly should not read that the bird is given permission to fast for a day; the reading seems to be fully causative. However, we can still see a motivation for "not intervene" as a part of an original composite conceptualization: having been put in a dark place, the animal should be left alone, and not be interfered with, with the specific effect of it not getting food for a day. Thus on the level of the whole we have an effected result, and in that sense a case of causation. It seems conceivable that speakers might have had such specific combinations stored as a whole and then used them when they wanted to talk about the production of this kind of effect, without computing in every case of use whether the context really justifies the use of a component concept of permission.

Now consider a case like (45), which modern readers also tend to interpret as causative.

$$
\begin{aligned}
& \ldots \text { die inghel ... daer niemen liet commen in } \\
& \ldots \text { the angel there no one let +PAST come in } \\
& \text {... the angel let nobody come in' }
\end{aligned}
$$

The angel is guarding the entrance to Paradise, thus he is the cause that nobody can come in. Notice that because of the negation, this is, on the level of the sentence as a whole essentially equivalent to saying that the angel did not allow anyone to enter. So this looks like another example of a specific pattern in which laten is a part, but which as a whole marks a result being caused, and may well have contributed to the number of contexts in which laten was associated with a causative reading and thus to the ultimate 'absorption' of this feature by the element, laten itself.

The last example I want to mention here is that of cases with inanimate causees such as the song in (46). 
(46) [si] liet daer vt gaen so sueten sanc/ende maecte daer so [she] let + PAST there out go so sweet song/and made there so edel geclanc

noble sound

'[She] let go-out such a sweet song/and made such noble sounds ...'

A song, or more generally a causee of this kind, contributes little to bringing about the effect, in this case its leaving the mouth, so that the sentence as a whole basically conveys an event of the subject referent being the only causal factor responsible for the result. In any case, what may have happened in this kind of scenario, is that gradually the typefrequency of laten $+V$ expressing causation (the number of specific holistic patterns with a causative reading and laten as a part), has increased, ultimately strengthening the connection between causation and laten to such an extent that it can now also be used in a sentence such as (47) with an animate causee - a type of combination that certainly is hard to find in older texts.
De sergeant liet
ons door de modder kruipen
The sergeant let+PAST us through the mud crawl
'The sergeant had/made us crawl through the mud.'

It will be clear that the actual investigation of this hypothesis requires the collection and systematic analysis of many examples, which has only recently begun; however, in view of the possibility of solving some longstanding problems by bringing in the usage-based perspective, it definitely looks promising.

\subsection{Morphology and syntax}

The final issue I will discuss concerns a cross-linguistic comparison of a morphological and a syntactic construction. Jackendoff (1997) contains a detailed analysis of what he calls the TIME-away construction in English; examples are in (48) and (49).

(48) Bill slept the afternoon away.

(49) We're twistin' the night away.

On the one hand, Jackendoff claims an independent status for this construction, while on the other he maintains the position that it shares important properties with more general patterns in the language:

This construction shares many general properties with the resultative construction $\ldots$ and the way-construction, ... however, ... it is a distinct member of a family of constructions to which all three belong. (Jackendoff 1997: 534) 
However, I think a comparative look can help us to see that these generalizations are really even less important than Jackendoff thinks. De Vries (1975), in his book on Dutch verbal morphology, analyzed the morphological category exemplified in (50) and (51); as is clear from these examples, this could at least count as the translation equivalent of the TIME-away construction.

(50) Hij had de hele middag verslapen

He had the whole afternoon ver-slept

'He had slept the entire afternoon away.'

(51) Ze hebben hun tijd verpraat

They have their time ver-chattered

'They chattered their time away.'

By prefixing a verb with ver-, the idea is evoked that the object is spent completely (in fact wasted) through the process the subject chose to engage in (denoted by the verb-stem). This raises the following question: How much does the fact that the English construction seems to belong to a family of syntactic patterns and the Dutch one to morphology, actually contribute to their identity? Does it help to explain anything about the differences between the two, beyond what is implied by what makes one a case of syntax and the other one of morphology? In discussing the syntactic difference between the Dutch and English way constructions, I noticed that they seemed to occupy rather different positions in the grammatical space of each language (one instantiating a ditransitive, the other a transitive pattern), but concluded that this actually contributed relatively little to an explanation of differences in the form and function of the constructions. In view of this, we may also be doubtful about the importance of the fact that similar work is done by morphological means in Dutch and syntactic ones in English. We could simply analyze the constructions in the two languages as in (52) and (53), and claim that this is basically what it comes down to.
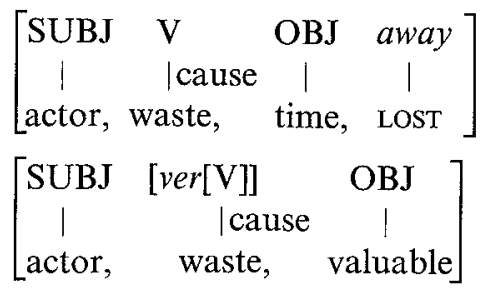

On a construction grammar view, similar linguistic behavior results from similarity of the symbolic relations involved, so we should expect that the ways in which the English construction (52) and the Dutch one in (53) are 
used and combine with other elements, are similar. In fact, they are. Firstly, consider the verbs listed in (54).

(54) verkwanselen 'bargain/fritter away, waste'; verkwisten 'waste, squander'; verspillen 'waste, fritter away'.

These are members of the relevant category, but they cannot be considered as blends of the construction and other elements, simply because the latter do not exist. The verbs share an aspect of form corresponding to an aspect of meaning: the prefix ver- and the concept of wasting; but there are no verbs kwanselen, kwisten or spillen. Thus, the role of the prefix here is one of formal similarity indicating semantic similarity, not one of a compositional element of the verbs. In English, as Jackendoff points out, there are verbs such as while and fritter, that occur only in the TIME-away construction, and this is of course precisely the same kind of situation. People have specific instances of the constructions, including their structure, stored in memory, as well as (slightly) more general patterns, some of which may be used productively.

Next, consider the data in Table 3 . In this table I listed the kinds of objects that some typical instances of the Dutch construction (taken from a large dictionary) apply to. There are some specific instances of conventionalization here, such as the specific association of the verb verspelen with objects that, apparently, evoke some notion of "opportunities" being wasted, without a specification of the nature of the activity that produces this result. But the same form verspelen may also be combined with an object that does not refer to time, but rather represents some money value (e.g., "a week's pay"), in which case the activity spelen 'play', is understood in its specific sense of "gamble"; there are several verbs taking this type of objects (category 4 in Table 3). And verbs indicating some form of talking (category 3) normally take objects indicating a period of time, but they may also mention money values in the "right" contexts, especially when time literally costs money: one can "chatter away" a fortune making long distance telephone calls.

Beyond these specifics, however, there is clearly also a general pattern: the objects in instances of this construction indicate things that are considered valuable. The fact that these, especially with certain kinds of activities, often involve time, does not have to come as a surprise, given the metaphorical mapping between time and money. Now according to Jackendoff, the English construction, as indicated by the name he gives it, requires objects indicating time. Although it cannot be excluded that such a specific kind of meaning is conventionally tied to an expression while a conceptually related one is not, it is not the kind of thing to be expected. General patterns express general conceptual aspects of situations, so it 
Table 3 Verbs with prefix ver- in Dutch and their objects

\begin{tabular}{|c|c|c|}
\hline & Semantics of object & Semantics of ver (ver-V) 'waste (by V-ing)' \\
\hline 1 & $\begin{array}{l}\text { Chances, rights, reputation } \\
{[ \pm \text { basis for future well-being }]}\end{array}$ & $\begin{array}{l}\text { verspelen }(\mathrm{N} \mathbf{B} \neq \text { ver }+ \text { spelen 'play, gamble' }) \text {, } \\
\text { 'waste, throw-away' }\end{array}$ \\
\hline 2 & +Time/-Money & $\begin{array}{l}\text { verdoen (met 'with' } X) \text { 'do }(\mathrm{X}) \text { ', verdromen 'dream', } \\
\text { verlummelen 'hang around', verslapen 'sleep' }\end{array}$ \\
\hline 3 & + Time/(+ Money $)$ & verkletsen, veriullen 'chatter', verpraten 'talk' \\
\hline 4 & -Time/+ Money & $\begin{array}{l}\text { verdobbelen 'play dice', vergokken 'gamble', } \\
\text { verroken 'smoke' verscheten 'shoot', } \\
\text { versnoepen 'eat candy', verspelen 'play, gamble', } \\
\text { verzuipen 'drink (alcohol)' }\end{array}$ \\
\hline
\end{tabular}

would be surprising if this shared cultural model - the time-as-moneymetaphor-would completely fail to show up in this pattern in English And in fact, such examples do show up A typical instance of the Dutch construction with its English translation is (55), and example (56) stems from the Brown-corpus

Hiy vergokte zyn erfenis

He ver-gambled his inheritance

'He gambled his inheritance away'

(56) But it is our health-more precious than all the money in the world - that these modern witch doctors with their fake therapeutic gadgets are gambling away

Example (56) is especially interesting in that it not only shows that the "X away construction" is avallable for expressing that something valuable has been wasted because of someone's activity, but explicitly invokes money, the prototypical instantiation of valuable commodities, as the standard of comparison There may be differences between the functions of the Dutch and English constructions, ${ }^{19}$ but it seems clear that in both languages, other valuable things than time occur in instances of this pattern, so the difference would at most concern the level in the taxonomy of constructions at which time is a conventionalized aspect of the meaning

How about the question What is the role of higher level generalizations as possible factors determining the properties of the constructions, in particular, the syntactic status in English, and the morphological status in Dutch? As we have seen above, Jackendoff claims that there are many such generalizations, suggesting that this captures an important insight For example, the English X-away construction belongs to the same family as the way construction, but the Dutch ver-V construction does not But it is actually quite unclear what kind of consequences, predictions about 


\section{A. Verhagen}

differences in linguistic behavior, should follow from such a statement. ${ }^{20}$ Jackendoff is much more successful in pointing out the peculiarities of the construction than its similarity to others; claims of the type "Important properties such as $\mathrm{X}$ are explained by the fact that this construction is related to that one" are in fact conspicuously absent. Assigning an important role to the general patterns would seem to entail the prediction that when such general patterns are different in another language, the constructions should really be different too, and that simply seems hard to substantiate.

\section{Conclusion}

I have been suggesting that the more abstract patterns of regularities in grammars may just be similarities between different specific symbolic units in a language, to a large degree more an effect than a cause of linguistic usage, and that what people actually use in understanding and producing language are relatively independent and specific patterns. This does not mean that these similarities have no causal role to play at all, but it is probably rather indirect; I suggested that it is more to be sought in relation to the interaction between linguistic experience and memory-favoring similar patterns and inhibiting dissimilar ones-than directly in relation to producing and understanding language.

Linguists might be worried that this view will deprive us of a way to see unity in language: "If the way we know our language is basically just a bunch of conventions, so that there are no deep structural principles uniting and constraining these bits of knowledge, doesn't the object of study loose its interest, because it is all so fragmented?" I suggest that the real problem here is the underlying assumption that the unity of the field should somehow exist in the unity of the linguistic system itself. Liberating ourselves from this structuralist prejudice, we may see that the source of the unity of linguistic structure may very well be external to it, that is, in the processes giving rise to all these bits of knowledge. For one thing, the idea of the usage-based approach in itself, which explains how the emergence of structure in the linguistic knowledge of individuals can lead to inverse processes on the level of communities, allows for unification of different perspectives in the study of language: psycholinguistics and historical semantics, or cognitive grammar and pragmatics. But there are also perspectives of unification on more specific levels, as we have seen, for example, in such processes as the development from possibility to causation in different parts of the grammar, and shared cultural models structuring the use and knowledge of formally different constructions in different languages. 
A powerful argument for seeking the unity of the field in the dynamic processes shaping language rather than in its structural properties as such, precisely resides in the possibility to unify the analysis of the development of Afrikaans inteendeel discussed at the beginning of this paper, and that of the (Dutch and English) way constructions analyzed later Both involve processes leading to the reduction of structure over time, in a process distributed over many individuals It must be conceptual content, not formal structure, that the processes operate on, since in the former case the conceptual structure is not correlated with formal structure to begin with Again, this does not mean that such a difference is never relevant (in particular, it is only symbolic structures in which elements of form correspond to components of meaning that allow for analogical extensions of a pattern, leading to new categories), but it is only by recognizing the essentially usage-based character of the structure of meaning (whether formally reflected or not) that the basic similarity of these processes can be captured

The 20th century has for linguistics certainly been the century of the dominance of structuralist thinkıng It did not start exactly in the year 1901, we usually set the beginnıng at 1916, the year that Saussure's Cours was published Perhaps future generations of linguists will, with their hindsight, put the end of the dominance of structuralism not exactly in the year 2000 etther, but for example in 1988, when Ronald Langacker published the paper coining the term 'usage-based model' But then they also just might make it the year 2000 anyhow, when the fully dynamicity of the approach was explicitly recognized (Langacker 2000)

Recelved 1 February 2002

Unversity of Lelden

Revision recelved 23 July 2002

\section{Notes}

* Author's e-mail address Arie Verhagen@let LeidenUnıv nl

1 I am grateful to the following colleagues, students, and friends for sharing their work with me and for comments on previous presentations of the ideas contained in this artıcle Willem Botha, Ad Foolen, Adele Goldberg, Gerhard van Huyssteen, Annelıes Kramer, Frank Landsbergen, Judith Loewenthal, Ariane van Santen, Joost Schilperoord, Elizabeth Traugott The usual disclaimers apply

2 http //www myarkpark com/waterberg/september 2000 htm, July 7, 2001

3 Interestingly, Afrukaans inteendeel seems to repeat part of the history of English in fact (Schwenter and Traugott 2000), at least in the crucial respect of developing from a marker of opposition (between statements of what is denied to be the case and what is really the casc) to a marker of reinforcement, not necessarily bound to a negative context

4 The Dutch examples were taken from the 1995 volume of the national newspaper de Volkskrant, avallable on CD ROM 
5 There are two sentences with two path-phrases and one with a conjunction of two prepositions ("over and preferably through X"), whence the total number in this table is three more than in Table 1

6 In fact, I think this can be confirmed by a detarled analysis of the few examples where the oblique phrase seems to be missing, but I will not undertake that here (cf Verhagen, in prep )

7 The relative prominence of this combination might be a feature of the specific corpus I used (a newspaper), so that this claim should be relativized with respect to genre, and perhaps also be restricted to a portion of the members of the language community None of this would change the general point

8 There are a number of idiomatic phrases exhibiting this pattern, frequently with a fully specified oblique phrase and often reflexive, e $\mathrm{g}$, zich iets in het hoofd halen, 'to get something into one's head' Furthermore, in some dialects something like a general benefactive pattern seems to be more productive than in the standard language None of this variation need surprise us in a constructional framework, of course

9 It is telling that learners do not take instances of the Dutch way construction as evidence for a general rule for benefactive constructions in the grammar-after all, instances of the construction clearly provide positive evidence for such a general rule, so why don't they put that into their mental grammar, and start using it productively? Rather than a "no negative evidence" problem, this suggests that at least for some areas, we might be forced to allow for the existence of a "positive evidence" problem This is actually just another illustration of the real complexity of the issue why learners do not construct overly general grammars (ef Bowerman 1988) It is conceivable that this case could be accounted for automatically by threshold-values for generalizations across instances of a pattern, for example in terms of type frequency I suggested in note 8 that cases of idiomatic three-participant patterns seem to be largely restricted to reflexives, if this is indeed the case, it would strongly limit the type-frequency of this pattern (cf Bybee and Hopper 2001 for a general discussion and different examples of this kind of relationships) Yet it is clear that we still lack much understanding of this important issue

10 Notice that this argument presupposes an important, possibly crucial, role for paradıgmatıc relations in the identification of constructions Syntagmatically, the two original English way constructions were already almost completely identical [Subj V POSS-way] The difference consisted of the knowledge that there were semantically distrnct subclasses (r e, paradigms) of verbs associated with two different senses of the same linear pattern The balance between syntagmatic and paradigmatic relationships in constructions is something that still requires much research

11 More than half of the students in my undergraduate Dutch syntax class in 2000 thought so when I asked them to think about 1t, which goes to show that regularity in actual usage need not at all be apparent when you just put two different but related grammatical patterns side-by-side, even when one focuses people's attention on the possibility that there might be differences As I show in the text, there really are significant differences

12 Kramer (2002) found a small number of indefinite cases of weg in apparent instances of construction B in 20th century material Further research will have to clarify whether these instances have some special properties, or whether definiteness is just a very strong constraint, and not an absolute requirement, for construction B in general

13 This distunction may be considered reminiscent of the 'lexical redundancy rules' in Jackendoff (1975), which were also meant to capture (morphological) relationships between words without deriving one kind of word from another (by transformational processes) However, at least one very important difference is that at the time, this 
proposal was believed to help keep syntax separate from lexicon and morphology, thus 'rescuing' a modular view of linguistic knowledge, while we now see that this type of phenomena occurs in syntax as much as anywhere else (as noted "in passing" by Langacker 200020 ) Obviously, this suggestion is also very much in the spirit of those made for morphology by Bybee (1995, among others), who furthermore links her ideas intimately to usage, in particular frequency (see also Bybee and Hopper 2001)

14 Naturally, schemas that do have the status of productive rules are also based on similarities between specific cases, and speakers may vary in what for them are only similanties, and what are conventional schemas Nevertheless I find it useful to think of things this way, in order to make the dependence of especially the general patterns on the specific instances clearly visible

15 For this section, I am especially indebted to Annelies Kramer, who wrote her MA thesis on this topic (Kramer 2002)

16 The prismatic model as such allows more than one route of interpretation, e g, first extension of the interpretation of the parts (along the horizontal lines at the top of the prism in Figure 13) and then combination of these extended meanings to the extended interpretation of the whole (along the vertical lines at the back of the prism in Figure 13), but also with the order reversed, or, conceivably, simultaneously, especially in the latter case an analysis of this kind looks similar to what we know as 'conceptual blending', but a further exploration of this idea is both beyond my own expertise and the framework of the present article In the case of the semantic development of the way construction, the most plausible route seems to be metaphorical extension of the combined interpretation followed or accompanied by extension of the interpretation of the parts, since way and level are clearly dependent on each other, $1 \mathrm{e}$, on the whole expression, for the association with "possibility" and "creating", respectively

17 Here I am drawing on work in progress by Judıth Loewenthal

18 In Der naturen bloeme, by Jacob van Maerlant, probably the most productive medieval Dutch author

19 It might be, for example, that the concept of "wasting" is slightly more prominent in the Dutch construction than in its English counterpart Cf Jackendoff's (1997 537) characterization "the subject is in some sense understood as 'using the time up' Some of this flavor appears in the second-approximation paraphrases Sam spent/wasted the afternoon sleeping

20 Another instantiation of this idea is that one construction may be "part of" morphology as well as syntax, or "In between" An illustration is Huysstcen's (2000) detailed study on reduplication constructions in Afrikaans, it will be clear that the rich diversity of the phenomena discussed by Huyssteen-some looking like complex words, some like phrases, yet all belonging to the same "network" of reduplication constructions--does not pose a problem in the present framework Another good example is Boolj's (2002) analysis of compound verbs in Dutch as constructions

\section{References}

Boolj, Geert

2002 Constructional 1dioms, morphology, and the Dutch Lexicon Journal of Germanic Lingulstics 14

Bowerman, Melissa

1988 The 'no negative evidence' problem How do children avold constructing an overly general grammar? In Hawkins J (ed ), Explaining Language Universals Oxford Blackwell, 73-101 
Bybee, Joan

1995 Regular morphology and the lexicon Language and Cognttive Processes 10, 425-455

Bybee, Joan and Paul Hopper (eds)

2001 Frequency and the Emergence of Lingustuc Structure Amsterdam/ Philadelphia Benjamıns

Croft, William

2000 Explaining Language Change An Evolutionary Approach Harlow, Essex Longman

Duinhoven, A M

1997 Middelnederlandse Syntax is Synchioon en Dtachroon Deel II De Werkwoordgroep [Middle Dutch Syntax synchronically and diachronically Part II The verb phrase] Groningen Martinus Nighoff

Fauconnier, Gilles

1994 Mental Spaces Aspects of Meaning Construction in Natural Language Cambridge Cambridge University Press [First edition 1985, Cambridge

Geeraerts, Dirk MA The MIT Press ]

1995 Specialization and reinterpretation in idioms In Everaert, Martın, Erık-Jan van der Linden, Andre Schenk, and Rob Schreuder (eds), Idloms Structural and Psychological Perspectives Hillsdale, NJ Lawrence Erlbaum, 57-73

Goldberg, Adele E

1995 Constructions A Construction Grammar Approach to Argument Structure Chicago/London The University of Chicago Press

1996 Makıng one's way through the data In Shibatanı, Masayoshı and Sandra A Thompson (eds), Grammatical Constructions Their Form and Meaning Oxford Oxford University Press, 29-53

Huyssteen, Gerhard B van

2000 Die reduplikasiekonstruksie in Afrikaans Enkele aspekte van 'n kognitiewe gebruksgebaseerde beskrywingsmodel vir Afrikaans [The reduplication construction in Afrikaans some aspects of a cognitive usage based model for Afrikaans] Unpublished $\mathrm{Ph} \mathrm{D}$ dissertation, Potchefstroomse Universiteit Israel, Michael vir Christelıke Hoer Onderwys, South-Africa

1996 The way constructions grow In Goldberg, Adele (ed), Conceptual Structure Discourse and Language Stanford, CA CSLI Publications, 217230

Jackendoff, Ray

1975 Morphological and semantic regularities in the lexicon Language 51, 639-671

1997 Twistın' the night awdy Language 73, 534-559

Kramer, Annelies

2002 De geschiedenis van de Nederlandse weg-constructıe [The history of the Dutch way construction] Unpublished MA thesis, Dept of Dutch, University of Lerden

Langacker, Ronald W

1988 A usage-based model In Rudzka-Ostyn, Brygida (ed ), Toptcs in Cognitive Lingutstics Amsterdam/Phıladelphra Benjamıns, 127-161

2000 A dynamic usage-based model In Barlow, Michael and Suzanne Kemmer (eds), Usage-Based Models of Language Stanford, CA CSLI Publications, $1-63$ 
Levinson, Stephen C

$2000 \quad$ Presumptive meanings The theory of generallzed conversational implicature Cambridge, MA The MIT Press

Schwenter, Scott $A$ and Elizabeth Closs Traugott

2000 Invoking scalarity The development of $m$ fact Journal of Historical Pragmatics 1, 7-25

Tomasello, Michael

2000 First steps toward a usage-based theory of language acquisition Cognttive Lingustucs 11, 61-82

Traugott, Elizabeth Closs

to appear Historical pragmatics In Horn, Laurence R and Gregory Ward (eds), Handbook of Pragmatics

Verhagen, Arie

2000a Interpreting usage Construing the history of Dutch causal verbs In Barlow, Michael and Suzanne Kemmer (eds), Usage-Based Models of Language Stanford, CA CSLI Publications, 261-286

2000b Concession implies causality, though in some other space In Couper-Kuhlen, Elizabeth and Bernd Kortmann (eds), Cause - Conditton - Concession Contrast Cognttve and Discourse Perspectives Berlin, New York Mouton de Gruyter, 361-380

2001 Subordination and discourse segmentation revisited, or Why matrix clauses may be more dependent than complements In Sanders, Ted, Joost Schilperoord and Wilbert Spooren (eds), Text Representation Linguistic and Psychological Aspects Amsterdam/Phıladelphı Benjamıns, 337-357

in prep The Dutch way

Verhagen, Arre and Suzanne Kemmer

1997 Interaction and causation Causative constructions in modern standard Dutch Journal of Pragmatics 27, 61-82

Vries, Jan W de

1975 Lexicale Morfologie yan het Werkwoord in Modern Nederlands [Lexical morphology of the verb in modern Dutch] Leiden Universitaire Pers

WNT

1882-1998 Woordenboek der Nederlandsche Taal [Dictionary of the Dutch Language]

Edited by M de Vries and L A te Winkel The Hague Nuhoff 